\title{
Keanekaragaman Vegetasi Riparian Sungai Polimaan, Minahasa Selatan - Sulawesi Utara (Riparian Vegetation Diversity of Polimaan River, South Minahasa- Sulawesi Utara)
}

\author{
Winda Puspita Bental(1), Ratna Siahaan ${ }^{1)^{*}}$, Pience V. Maabuat ${ }^{1)}$ \\ 1) Program Studi Biologi, Jurusan Biologi FMIPA UNSRAT, Manado 95115 \\ ${ }^{\star}$ Email korespondensi: ratna245_siahaan@yahoo.com
}

Diterima 5 Februari 2017, diterima untuk dipublikasikan 28 Februari 2017

\begin{abstract}
Abstrak
Degradasi riparian akibat aktivitas manusia dapat menyebabkan penurunan vegetasi riparian yang akan berdampak pada fungsi dalam mempertahankan kualitas air sungai, habitat hidupan liar dan menurunkan jasanya bagi kesejahteraan manusia. Penelitian vegetasi riparian Sungai Polimaan dilakukan untuk menganalisis keanekaragaman vegetasi riparian Sungai Polimaan. Penelitian dilakukan dari Desember 2016 sampai Maret 2017 di sepanjang sungai dari hulu, tengah hingga hilir Sungai Polimaan. Metode analisis vegetasi transek petak sistematik dilakukan pada tingkat rumput, semai, pancang, tihang dan pohon. Vegetasi riparian yang ditemukan di Sungai Polimaan sebanyak 665 individu, 68 spesies, 41 suku. Keanekaragaman vegetasi riparian $\left(H^{\prime}\right)$ secara keseluruhan tergolong sedang untuk tingkat rumput $(1,55)$, pancang $(1,53)$, tihang $(1,64)$ dan pohon $(1,76)$ dan tergolong tinggi pada tingkat semai $(3,59)$. Upaya pengelolaan zona riparian diperlukan untuk mempertahankan keanekaragaman vegetasi riparian di Sungai Polimaan.

Kata kunci: keanekaragaman, Sungai Polimaan, vegetasi riparian.
\end{abstract}

\section{Abstract}

Riparian degradation due to human activities can lead to decreased riparian vegetation that affects riparian function to maintain river quality, wildlife habitat and riparian services for human well-being. The riparian vegetation research of the Polimaan River was conducted to analyze the diversity of riparian vegetation of the Polimaan River. The study was conducted from December 2016 to March 2017 along river from upper, middle to down the Polimaan River. Method of systematic transect vegetation analysis was carried out at the levels of grass, seedling, stake, banana and tree. The riparian vegetation found in the Polimaan River consisted of 665 individuals, 68 species, 41 families. Riparian vegetation diversity $(H$ ') could be classified into middle diversity for grass (1.55), sapling (1.53), poles (1.64) as well as tree (1.76), and high diversity for seedlings (3.59). Riparian zone management are required to preserve the diversity of riparian vegetation of Polimaan River.

Key words: biodiversity, Polimaan River, riparian vegetation

\section{PENDAHULUAN}

Riparian adalah ekosistem peralihan (ecotone) yang memiliki fungsi ekologis dan manfaat penting bagi keberlanjutan kehidupan organisme dan kesejahteraan manusia. Keberadaan vegetasi 
riparian berdampak penting secara ekologis bagi sungai. Vegetasi riparian berfungsi antara lain untuk menjaga kualitas air sungai melalui pengaturan suhu air (Mitsch dan Gosselink 1993), pemasok serasah (Jones et al. 1999) dan penjerapan pencemar dari daratan (Tourbier 1994), habitat bagi organisme (Sparks 1995, Jones et al. 1999). Degradasi riparian disebabkan oleh berbagai aktivitas manusia yang memanfaatkannya untuk berbagai macam kebutuhan manusia akan lahan dan sumberdaya lainnya. Hal ini dapat mempengaruhi fungsi ekologis sungai.

Fungsi dan manfaat riparian yang sangat penting tersebut perlu dipertahankan dengan melakukan upaya konservasi riparian. Upaya ini membutuhkan data ilmiah termasuk data keanekaragaman vegetasi riparian. Sungai Polimaan, yang merupakan sungai utama Daerah Aliran Sungai Polimaan, terletak di Kabupaten Minahasa Selatan. Sungai ini berperan penting sebagai penyedia air irigasi pertanian. Penelitian tentang keanekaragaman vegetasi riparian Sungai Polimaan diperlukan sebagai data base keanekaragaman vegetasi riparian agar konservasi vegetasi riparian dapat dilakukan.

\section{METODE}

\section{Waktu dan Tempat}

Penelitian dilakukan dari bulan Desember 2016 sampai Maret 2017. Lokasi penelitian di Sungai Polimaan Minahasa Selatan, Sulawesi Utara. Metode purposive sampling digunakan dalam penentuan lokasi penelitian dari hulu (Stasiun I), tengah (Stasiun II) dan hilir (Stasiun III) Sungai Polimaan. Stasiun I di Desa Lowian 1, Kecamatan Maesaan, Stasiun II di Desa Sion, Kecamatan Tompaso Baru dan Stasiun III di Desa Torout, Kecamatan Tompaso Baru.

\section{Alat dan Bahan}

Alat dan bahan yang digunakan ialah alat dan bahan yang umum digunakan di lapangan dan laboratorium seperti GPS, kamera digital, gunting tanaman, pita ukur, oven, alkohol dan kertas koran.

\section{Teknik Pengambilan Sampel}

Pengambilan sampel vegetasi riparian di lokasi yang telah terpilih dilakukan dengan menggunakan metode analisis vegetasi transek petak sistematik. Penempatan petak penelitian dilakukan pada kedua sisi kiri dan kanan sungai. Ulangan sebanyak 3 kali pada tiap stasiun. Jarak ulangan di tiap stasiun kurang lebih $10 \mathrm{~m}$. Ukuran petak ditentukan dengan menggunakan kategori pengelompokan Istomo dan Kusmana (1997), yaitu $1 \mathrm{~m} \times 1 \mathrm{~m}$ untuk rumput, 2 $\mathrm{m} \times 2 \mathrm{~m}$ untuk semai, $5 \mathrm{~m} \times 5 \mathrm{~m}$ untuk pancang, $10 \mathrm{~m} \times 10 \mathrm{~m}$ untuk tihang dan $20 \mathrm{~m} \times 20 \mathrm{~m}$ untuk pohon. Identifikasi dilakukan di Herbarium Bogoriense LIPI, Bogor dan Laboratorium Ekologi, Jurusan Biologi, FMIPA Universitas Sam Ratulangi, Manado.

\section{Analisis Data}

Analisis data kepadatan, frekuensi, dan Indeks Nilai Penting digunakan dalam menghitung Indeks Keanekaragaman Spesies Shannonwiener ( $\left.\mathrm{H}^{\prime}\right)$. Nilai $\mathrm{H}^{\prime}$ dihitung berdasarkan rumus Stiling (1992) sebagai berikut:

Keterangan:

$$
H^{\prime}=-\sum p_{i} \ln p_{i}
$$

$H^{\prime}=$ Indeks Keanekaragaman Spesies

Shannon-Wiener

$\mathrm{p}_{\mathrm{i}}=$ peluang untuk tiap spesies $\left(\mathrm{n}_{\mathrm{i}} / \mathrm{N}\right)$

$\mathrm{n}_{\mathrm{i}}=$ INP tiap spesies

$\mathrm{N}=$ Nilai total INP untuk seluruh spesies Nilai $H^{\prime}$ tersebut digunakan dalam klasifikasi tingkat 
keanekaragaman spesies menurut Fachrul (2007) sebagai berikut:

- Nilai H' > 3 menunjukan keanekaragaman species tinggi

- $\quad$ Nilai H' $1 \leq \mathrm{H}^{\prime} \leq 3$ menunjukan keanekaragaman species sedang

- Nilai $H^{\prime}<1$ menunjukan keanekaragaman species rendah atau sedikit.

\section{HASIL DAN PEMBAHASAN Rumput}

Indeks Keanekaragaman spesies vegetasi riparian pada tingkat pertumbuhan di Sungai Polimaan berdasarkan kategori pengelompokan rumput, semai, pancang, tihang dan pohon. Vegetasi rumput tidak ditemukan di Stasiun I bagian hulu. Nilai H' di Stasiun II, III dan Sungai Polimaan (keseluruhan) berturut-turut 0,69 (rendah); 1,01 (sedang) dan 1,55 (sedang). Ketidakhadiran rumput di Stasiun I disebabkan karena area masih tertutup oleh tutupan pohon yang menghambat penetrasi cahaya ke permukaan tanah untuk pertumbuhan rumput. Persaingan yang cukup ketat dalam mendapatkan unsur cahaya menyebabkan rumput tumbuh kurang optimal (Hani dan Effendi 2009).

\section{Semai}

Nilai Indeks H' tingkat semai di Sungai Polimaan tergolong tinggi $(3,59)$. Indeks keanekaragaman pada stasiun lainnya termasuk sedang, yaitu Stasiun I $(2,54)$, Stasiun II $(2,45)$ dan Stasiun III $(2,74)$. Vegetasi semai di lokasi penelitian termasuk tinggi karena lokasi penelitian dengan ciri tanah yang lembab, berair dan cahaya matahari yang cukup memungkinkan vegetasi tingkat semai tumbuh dengan baik. Keanekaragaman vegetasi semai dipengaruhi oleh penetrasi cahaya matahari yang masuk ke permukaan tanah (Hilwan et al. 2013). Tumbuhan bawah seperti semai juga dapat tumbuh dengan baik di zona riparian yang lembab dan terbuka. Anakan vegetasi semai ini menunjukkan adanya upaya pemulihan riparian setelah adanya gangguan.

\section{Pancang}

Keanakaragaman vegetasi riparian tingkat pancang di Stasiun II dan Stasiun III termasuk rendah dengan nilai $H^{\prime}$ yaitu 0,68 dan 0,00 serta tergolong sedang di Stasiun I dengan nilai $H^{\prime}$ yaitu 1,70. Keanekaragaman vegetasi riparian tingkat pertumbuhan pancang secara keseluruhan di lokasi penelitian termasuk sedang $\left(H^{\prime}: 1,53\right)$. Stasiun I di bagian hulu ialah area yang belum banyak menerima gangguan akibat aktivitas masyarakat setempat, sehingga memungkinkan vegetasi riparian tingkat pancang dapat tumbuh dengan baik. Semakin meningkatnya aktivitas manusia di lokasi penelitian Stasiun II dan III menyebabkan vegetasi berkurang dan mengakibatkan semakin rendahnya indeks keanekaragaman. Pola pemanfaatan lahan pertanian yang semakin meningkat ke hilir mengakibatkan perubahan zona riparian.

\section{Tihang}

Keanekaragaman vegetasi tingkat tihang di Stasiun I termasuk sedang $\left(H^{\prime}\right.$ : 1,59$)$ tetapi di Stasiun II dan III termasuk rendah ( $H^{\prime}:$ 0,6 dan 0 ). Vegetasi riparian tingkat tihang tidak ditemukan di lokasi penelitian Stasiun III, sehingga nilai H' sangat rendah. Keadaan lokasi Stasiun I masih cukup baik, sehingga pertumbuhan vegetasi riparian tingkat pancang maupun tihang masih baik. Indeks 
keanekaragaman pada Stasiun II dan III tergolong rendah akibat adanya perubahan riparian menjadi lahan pertanian. Secara keseluruhan, keanekaragaman vegetasi riparian di Sungai Polimaan tingkat tiang termasuk sedang $\left(H^{\prime}: 1,64\right)$ dan hal ini menunjukkan keanekaragaman vegetasi riparian tingkat tihang di Sungai Polimaan masih terjaga. Walaupun demikian pemanfaatan riparian di Sungai Polimaan tetap perlu dikendalikan terutama di bagian hulu untuk mempertahankan fungsi riparian dalam mempertahankan kualitas air sungai.

\section{Pohon}

Indeks keanekaragaman pada tingkat pohon di Stasiun I dan Stasiun II tergolong sedang (H': 1,05 dan 1,1). Indeks keanekaragaman $\mathrm{H}^{\prime}$ di Stasiun III sangat rendah karena tidak ditemukannya pohon. Keanekaragaman vegetasi riparian tingkat pohon di lokasi penelitian Sungai Polimaan termasuk sedang $(1,76)$. Keanekaragaman vegetasi riparian pada tingkat pohon yang sangat rendah di Stasiun III terutama disebabkan pohon tidak ditemukan akibat peningkatan aktivitas masyarakat setempat seperti pertanian, permukiman dan pertambangan pasir dan batuan. Pola pemanfaatan zona riparian untuk kebutuhan masyarakat setempat seperti pertanian, lahan permukiman, industri, dan penguatan tebing menjadi penyebab hilangnya vegetasi riparian (Malanson 1995, Maryono 2005).

\section{Indeks Keanekaragaman Vegetasi Riparian Sungai Polimaan}

Tingkat keanekaragaman spesies menunjukkan tingkat stabilitas ekosistem. Semakin tinggi indeks keanekaragaman, maka semakin stabil ekosistem tersebut (Ismaini et al.
2015). Keanekaragaman vegetasi riparian di lokasi penelitian tergolong sedang untuk tingkat rumput $(1,55)$, pancang $(1,53)$, tihang $(1,64)$ dan pohon $(1,76)$ serta tergolong tinggi pada tingkat semai $(3,59)$. Semai merupakan tumbuhan bawah yang berfungsi sebagai penahan pukulan air hujan dan aliran permukaan sehingga meminimalkan bahaya erosi. Semai juga sering dijadikan sebagai indikator kesuburan tanah dan penghasil serasah dalam meningkatkan kesuburan tanah.

Keanekaragaman vegetasi riparian Sungai Polimaan perlu dijaga dan dipertahankan mengingat fungsi dan manfaat vegetasi riparian yang penting dalam mempertahankan kualitas air sungai yang dimanfaatkan oleh masyarakat setempat untuk mengairi sawah mereka. Penurunan keanekaragaman vegetasi riparian juga dapat berdampak pada penurunan kualitas air.

\section{KESIMPULAN}

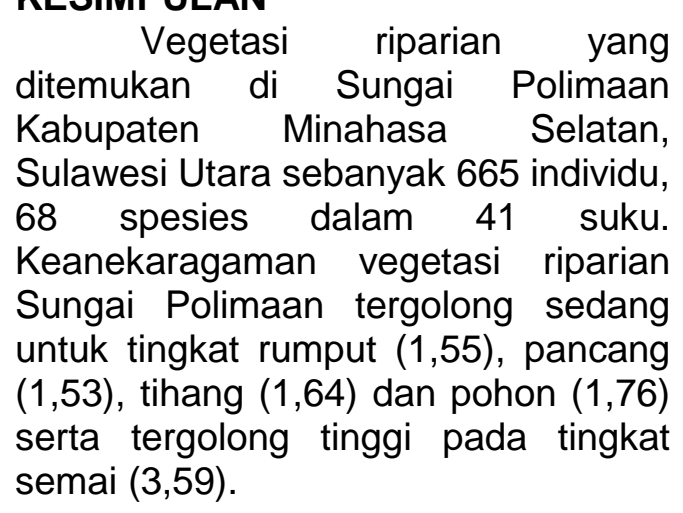

\section{DAFTAR PUSTAKA}

Fachrul MF (2007) Metode sampling bioekologi. Edisi ke-1. Bumi Aksara, Jakarta

Hani A, Effendi R (2009) Potensi permudaan alam tingkat semai (Khaya antotecha) di Hutan Penelitian Pasir Hantap, Sukabumi, Jawa Barat. Bogor. 
Mitra Hutan Tanaman 14(2): 4956

Hilwan A, Mulyana D, Pananjung WG (2013) Keanekaragaman jenis tumbuhan bawah pada tegakan sengon buto (Enterolobium cyclocarpum Griseb.) dan trembesi (Samanea saman Merr.) di lahan pasca tambang batubara PT Kitadin, Embalut, Kutai Kartanagara, Kalimantan Timur. Departemen Silvikultur, Fakultas Kehutanan Institut Pertanian Bogor, Bogor

Istomo, Kusmana C (1997) Penuntun praktikum Ekologi Hutan. Laboratorium Ekologi Hutan, Fakultas Kehutanan, Institut Pertanian Bogor, Bogor

Ismaini L, Masfiro L, Rustandi, Dadang $S$ (2015) Analisis komposisi dan keanekaragaman tumbuhan di Gunung Dempo, Sumatera Selatan. UPT Balai Konservasi Tumbuhan Kebun Raya Cibodas. Lembaga IImu Pengetahuan Indonesia (LIPI). Prosiding Seminar Nasional Masyarakat Biodiversitas Indonesia 1(6): 1397-1402
Jones EBD, Helfman GS, Harper JO, Bolstad PV (1999) Effects of riparian forest removal on fish assemblages in Southern Appalachian streams. Conservation Biology 13 (6): 1454-1465

Maryono A (2005) Menangani banjir, kekeringan dan lingkungan. Gadjah Mada University Press, Yogyakarta

Malanson GP (1995) Riparian landscapes. Cambridge University Press, Cambridge

Mitsch WJ, Gosselink JG (1993) Wetlands. Edisi ke-2. Van Rostrand Reinhold, New York

Stiling P (1992) Ecology theories and application. 2nd Edition. Prentice Hall International Inc, New York

Sparks RE (1995) Need for ecosystem management of large rivers and their floodplans. Bio Science 45(3): 168-182

Tourbier JT (1994) Open space through storm water management. J Soil and Water Cons 49(1): 14-21 